\title{
Differentiated Integration of Core State Powers
}

\author{
Berthold Rittberger \\ Dirk Leuffen \\ Frank Schimmelfennig
}

\begin{abstract}
Keywords
A prominent feature of European integration is its differentiated character, which refers to a state of territorial or horizontal fragmentation across different policy areas. In a horizontally fragmented polity, EU member states demand 'optouts' from sectoral policy integration, monetary integration being the prime example. Moreover, non-EU member states are granted participation in certain EU policy regimes, such as the Schengen area or the common market.

Differentiated integration thus runs counter to the notion propagated by the EU's 'founding fathers' of establishing an 'ever closer union' in which uniform integration among its member states would be the norm. This chapter first highlights the different patterns of differentiated integration between core state and non-core state powers. In a second step, the explanatory model developed by the editors is employed and adapted to explain patterns of differentiated horizontal integration by focusing on three instances of core state powersmonetary policy, defence policy and internal security-as well as market integration as a contrasting case of a non-core state power.
\end{abstract}

Keywords: Differentiated integration, territorial fragmentation, monetary policy, defence policy, internal security, market integration 


\subsection{Introduction}

An increasingly prominent feature of European integration is its differentiated character. After several decades of relative stagnation, the integration process was re-launched with the Single European Act (SEA) in the late 1980s and the Treaty of Maastricht in the 1990s. At the same time, several EU member states demanded 'opt-outs' from sectoral policy integration, monetary integration being the prime example. Moreover, non-EU member states were granted participation in certain EU policy regimes, such as the Schengen area or the common market. Differentiated integration points to a process of territorial or horizontal fragmentation, which runs counter to the notion propagated by the EU's 'founding fathers' of establishing an 'ever closer union' in which uniform integration among its member states would be the norm. The goal of this chapter is twofold. First, we introduce differentiated integration as a concept to capture variation in the extent to which policy areas are integrated horizontally. Moreover, we illustrate patterns of differentiated integration by distinguishing between core state powers and non-core state powers. Second, we employ the explanatory model presented in the framework chapter to explain patterns of differentiated horizontal integration in the EU. For instance, is monetary policy integration characterized by internal differentiation, whereby a substantial minority of EU member states has not adopted the common currency? Why do EU member states opt out of being part of the Schengen area while, at the same time, non-EU member states have signed up to the measures abolishing border controls? Why is the (p.190) internal market characterized by uniform integration, with all EU member states taking part in it? Moreover, why do nonEU member states wish to join the EU's internal market by participating in the European Economic Area (EEA)?

In this chapter, we argue that differentiation results from an interaction of the relative 'depth' of integration and the attributes of a policy area. We argue that for non-core state powers, such as the policies pertaining to the establishment of the common market, there is a rather small likelihood of so-called internal differentiation, meaning that EU member states opt out of specific policy regimes. At the same time, there are considerable incentives for non-EU member states to join since functional motives are not constrained by identity concerns. For core state powers, we argue that there tends to be a higher likelihood for internal differentiation the deeper policy integration and hence more centralized decision-making becomes. The reason for this is that transferring sovereignty in matters of core state powers, such as monetary or defence policy, tends to trigger critical reactions by Eurosceptic publics.

10.2 Core State Powers and Differentiated Integration: Conceptual Clarifications 
Core state powers, i.e. coercive power (military and police), public finance, and public administration, have been integral in the process of modern state building. Consequently, when the locus of decision-making for core state powers shifts from the nation state to the supranational level, we witness a move towards increased 'state-ness' of the EU. The main thrust of this chapter is that the shifts towards increased state-ness of the EU do not proceed in a uniform fashion, but are characterized by territorial or horizontal differentiation. Such differentiation captures variation in the participation of member states and nonmember states across policies. Some integrated policies apply to the entire EU (and even to several non-member states) whereas others exclude or exempt EU member states. Not all EU member states are participating uniformly when new policies are being integrated or new levels of centralization agreed upon. As a consequence, opt-outs or measures of flexible integration have come to leave their imprint on European integration. Moreover, non-EU member states participate increasingly in EU policies, thereby adopting a policy sector specific acquis. For example, while EU member states, such as the UK and Ireland, have decided to opt out of 'Schengenland', the EU's policy of unrestricted crossborder travel, non-EU (p.191) members, such as Switzerland, Norway, Iceland, and Liechtenstein have signed up to the Schengen regime.

We distinguish between four qualitatively different constellations of territorial differentiation: (1) the uniform, complete and exclusive application of treaty rules (no differentiation), (2) external differentiation, (3) internal differentiation, and (4) the combination of external and internal differentiation. In the first case, EU rules apply uniformly and exclusively to all member states. This is the paradigmatic case of integration, which adequately describes the first four decades of the integration process. Ardent Euro-federalists still equate differentiation with fragmentation and consider it a threat to the integration project and a violation of the founding fathers' ideal of attaining 'ever closer union'.

If, however, EU rules apply uniformly to all member states but outsiders formally adopt these rules as well, we observe an externalization of the acquis communautaire (external differentiation). The free movement of goods and services is a telling example: all 28 members of the EU are subject to the provisions governing the free movement of goods and services. However, the non-EU member states of the EEA, Iceland, Liechtenstein, and Norway, have also enacted EU legislation on the free movement of goods and services. The EU's internal market is thus effectively extended to the whole of the EEA. Switzerland, which is not a member of the EEA, has negotiated bilateral agreements with the EU, one of which covers trade in industrial goods. It can thus be argued that the provisions governing the free movement of goods and services extend beyond the ring of EU member states, to cover 30 states (or even 31, if we also include Switzerland). 
A third form of differentiation is internal differentiation: EU rules cease to apply uniformly to all EU member states, since individual member states decide to opt out of membership in a particular policy area. The Treaty of Maastricht marks a milestone in this regard as it paved a legal avenue for this form of differentiation. Opt-outs with regard to two core state powers are paradigmatic in this regard. In monetary policy two member states, Denmark and the UK, negotiated concessions so that they could opt out of the single currency. Presently, 18 out of 28 EU member states have renounced their domestic currencies in favor of the Euro. With a view to security and defence policy, where the Treaty of Maastricht equally marked a watershed by deepening the level of centralization, Denmark was granted an opt-out in defence-related matters. The trend that started in Maastricht continued in the Treaties of Amsterdam, Nice, and the Lisbon Treaty which formally enshrined and extended the possibility for territorial differentiation via the mechanism of 'enhanced cooperation' to security and defence-related (p.192) matters. The Lisbon Treaty thus highlights and expands the formal possibility to form subgroups of the 'willing'.

Fourth, external and internal differentiation can be combined. This occurs when 'insiders', one or more EU member states, decide to opt out of a certain policy while 'outsiders', one or more non-EU member states, opt in by subjecting themselves to EU rules. A prominent example is the Schengen border regime. Following its inception in 1985, many EU member states have joined the border regime (with the exception of Bulgaria, Cyprus, Ireland, Romania, and the UK) as well as four non-EU member states, Iceland, Liechtenstein, Norway, and Switzerland. Currently, 'Schengenland'-an area without internal border controls and a uniform external border-consists of 26 states. In the remainder of this chapter, we explore the relationship of these types of differentiation with the integration of core and non-core state powers.

\subsection{Patterns of Differentiated Integration: Comparing Core State Powers} with Non-core State Powers

In this section, we present the data on differentiated integration for core state powers as well as for non-core state powers. We group different policy areas into two broad categories, core state powers and non-core state powers. The former comprise matters of external security (i.e. security and defence policy) as well as internal security (i.e. criminal and domestic policies), fiscal, monetary and tax policies. The latter category comprises regulatory policies (i.e. market-making and market-correcting policies) as well as expenditure policies, such as the common agricultural policy, cohesion policy and research and development (R\&D). ${ }^{1}$ 
Figure 10.1 displays the number of policy areas per decade grouped by the different categories of horizontal differentiation introduced earlier. In the first decades of European integration 'uniformity' was the rule and there was (if at all) only temporal differentiation (in the context of enlargement rounds). The 1980s mark a watershed: differentiation took off with the SEA and it has become more prominent and diverse since then. Currently, less than half of the 18 policy areas still conform to the idea of uniform and complete integration among all EU member states. In addition, we find significant variation in the types of differentiation across policy areas.

\section{(p.193)}

Inspecting the 2010 data more closely, the distinction between core and non-core state powers seems to correspond closely to particular patterns of differentiation (see Table 10.1). Beginning with non-core state powers, two types of territorial differentiation dominate the picture: uniform integration and external differentiation. At the same time, there is no internal and no external and internal

differentiation in the integration of non-core state powers.

We can further classify non-core state powers into regulatory and expenditure or distributive policies. This classification reveals that the external differentiation of integration of non-core state powers is dominated by regulatory policies, both market-making (economic freedoms) and marketcorrecting, such as environmental regulation, consumer protection, occupational health and safety standards, labour, competition, and industry policy. Only research and development as well as transport policies have a decidedly distributive component. By contrast, the most important (and costly) expenditure policies of the EU remain uniformly integrated and reserved for member states: agriculture, cohesion, and welfare. 
The pattern of differentiated integration for core state powers is different than for non-core state powers. We witness uniform integration in fiscal policy (which is already becoming internally differentiated in the context of the 'Euro-crisis') and taxation (albeit at a rather low level of integration), internal differentiation in monetary as well as security and defence policy, and a combination of internal and external differentiation in the fields of domestic (p.194)

\section{Table 10.1 Differentiation by type: core/non-core state powers (as} of 2010)

\begin{tabular}{|c|c|c|}
\hline & $\begin{array}{l}\text { Core state } \\
\text { powers }\end{array}$ & Non-core state powers \\
\hline $\begin{array}{l}\text { Uniform } \\
\text { integration }\end{array}$ & $\begin{array}{l}\text { Fiscal policy; } \\
\text { taxation }\end{array}$ & $\begin{array}{l}\text { Economic external relations; civil matters; } \\
\text { culture; welfare; agriculture, territorial, } \\
\text { economic and social cohesion }\end{array}$ \\
\hline $\begin{array}{l}\text { External } \\
\text { differentiation }\end{array}$ & - & $\begin{array}{l}\text { Environment and consumer protection; } \\
\text { occupational health and safety standards; } \\
\text { labour; research and development; economic } \\
\text { freedoms; competition and industry; energy } \\
\text { and transport }\end{array}$ \\
\hline $\begin{array}{l}\text { Internal } \\
\text { differentiation }\end{array}$ & $\begin{array}{l}\text { Security and } \\
\text { defence; } \\
\text { monetary } \\
\text { policy }\end{array}$ & - \\
\hline $\begin{array}{l}\text { External and } \\
\text { internal } \\
\text { differentiation }\end{array}$ & $\begin{array}{l}\text { Criminal and } \\
\text { domestic } \\
\text { security }\end{array}$ & - \\
\hline
\end{tabular}

security and criminal policies. Internal differentiation is an exclusive feature of integration in core state powers, and there is no external differentiation without internal differentiation.

We will now turn to explaining the aforementioned patterns of differentiated integration over time and across policy types. Three questions about the integration of core state powers stand out. First, why is internal differentiation limited to the integration of core state powers? Second, why is external differentiation so much more frequent in the integration of non-core state powers than in the integration of core state powers? Finally, why are some core state powers uniformly integrated whereas the integration of others is differentiated?

10.4 Explaining Patterns of Differentiated Integration: Core State Powers, Identity, and Politicization 
In their Introduction to the volume, the editors propose a demand-and-supply framework for explaining the integration of core state powers. It links demand to policy externalities and economies of scale, and supply to willingness and capability driven by either majoritarian or non-majoritarian actors (Genschel and Jachtenfuchs, this volume). Such a framework is also useful for mapping explanations of differentiation (Leuffen et al. 2013).

First, differentiated integration can be understood as a response to differences in demand. Countries are differentially affected by policy externalities or benefit differently from economies of scale. At the level of policy areas, we (p.195) can formulate the following conjecture: Integration in a policy area is the more likely to be differentiated, the more differently the states participating in integration are affected by externalities and economies of scale in this policy area. This is in essence a functionalist hypothesis: patterns of integration follow patterns of interdependence.

Conversely, supply-side explanations of differentiated integration come in a neofunctionalist or a postfunctionalist variety. Whereas neofunctionalism predicts oversupply, postfunctionalism expects undersupply relative to demand. If we assume a given demand-side pattern, the non-majoritarian actors of European integration-such as the Commission, the Court, or the European Central Bank-use their competences and capabilities to uphold or increase uniform integration 'by stealth'. For instance, the Commission tends to make uniform legislative proposals, the Court cares about a uniform application of European law, and the European Central Bank seeks to preserve the Eurozone. Correspondingly, integration in a policy area is the more likely to be differentiated, the weaker the capabilities of (non-majoritarian) supranational actors are in this policy area. This is the neofunctionalist hypothesis.

By contrast, postfunctionalism (Hooghe and Marks 2009) stresses the constraints of public, majoritarian politics on demand-based integration. Publics and voters are likely to reject or limit integration if they perceive themselves as economic losers of integration or if they perceive supranational integration to undermine their national or regional identity. 'Low politics' areas with weak redistributive impact or weak relevance for national identity are weakly politicized and can thus escape the 'constraining dissensus' (Hooghe and Marks 2009). They are conducive to uniform integration provided that demand is homogeneous. But 'high politics' areas profoundly affect national sovereignty and identity; they are characterized by transnational distributional conflict, and - as a consequence-tend to be more politicized and are less likely to be integrated in Eurosceptic countries. Correspondingly, integration in a policy area is the more likely to be differentiated, the more politicized this policy area is. 
How do these arguments map onto the distinction between core and non-core state powers, on the one hand, and the different types of differentiated integration, on the other? As for core and non-core state powers, there is no theoretical reason to assume that they differ systemically with regard to demand for integration. In principle, security or fiscal and monetary interdependence may be as strong and heterogeneous as interdependence in, say, transport, the environment, or trade. By contrast, there is a theoretically plausible distinction between core and non-core state powers as concerns the supply side of integration.

(p.196) First, we assume that organizations are unwilling to give up or share those powers that are constitutive for their identity, are crucial for their autonomy and survival, and provide them with a competitive edge over other types of organizations. Almost by definition, states are thus unwilling or reluctant to transfer core state powers to supranational organizations. This entails that the capabilities of non-majoritarian supranational organizations are likely to be comparatively weak in policy areas belonging to the realm of core state powers and are thus unable to prevent or constrain differentiation.

Second, and more importantly, the integration of core state powers is likely to be more politicized than the integration of non-core state powers because core state powers are highly relevant from the vantage point of national identity. The national currency and the national army are far stronger symbols of national identity than the national competition authority or trade commission; giving up control of borders, migration, and defence is likely to be considered a stronger identity threat than giving up control of trade, transport or research policies; and the integration of fiscal policy requires more transnational solidarity than the integration of environmental policy.

Following this line of argument, core state powers are less likely to be supranationally integrated than non-core state powers. If the latter are integrated, integration should occur at a lower level of centralization than the integration of non-core state powers (Leuffen et al. 2013). Moreover, we are most likely to see the uniform integration of core state powers if integration remains at an intergovernmental level of centralization. As long as joint decisions regarding core state powers are taken unanimously and competences are not delegated to supranational organizations, national governments remain in charge and national identity is not threatened. As a result, there is a good chance that integration is not politicized. 
This applies to the areas of core state powers classified as uniform integration in Table 10.1. Taxation is one of the few policy areas that still require unanimous decisions in the Council. Fiscal policy is weakly integrated as well. It is regulatory rather than redistributive, and its regulatory core, the Excessive Deficit Procedure, is intergovernmental in essence: it does not involve the Court or the Parliament, and the decision to impose sanctions requires a qualified majority of member states. Intergovernmental decision-making is not a sufficient condition for uniform integration: defence policy is internally differentiated (but only very slightly) in spite of intergovernmental procedures. Yet, there is no uniform supranational integration of core state powers. In line with this pattern, the strengthening and supranationalization of fiscal surveillance has led to internal differentiation: the quasi-automatic sanctions of the reformed Stability and Growth Pact only apply to Eurozone countries, and the UK and the Czech Republic refused to sign the Fiscal Pact.

(p.197) Internal differentiation thus results from the integration of core state powers, which produces concerns about state autonomy in general and national identity in the more Eurosceptic member states in particular. These member states support the supranational regulation of the internal market but are opposed to more centralization of core state powers at the EU level. External differentiation is the mirror image of internal differentiation. States that are unwilling and unable to join the EU due to the opposition of Eurosceptic publics and electorates, but are strongly interdependent with the EU's internal market are willing and able to adopt the EU's non-politicized market-related regulatory policies. On the basis of these theoretical considerations regarding demand-andsupply conditions of integration, we can now formulate general explanations for the patterns of differentiation established in the previous section.

The strong correlation between internal differentiation and the integration of core state powers is explained by the politicized nature of integration in these policy areas. Member states do not seek opt-outs from the integration of noncore state powers because it does not produce high autonomy costs or identity concerns. We therefore do not find internal differentiation in the integration of non-core state powers. By contrast, comparatively Eurosceptic member states, which garner strong identity concerns, tend to seek opt-outs from the integration of core state powers. We therefore find internal differentiation in integrated policies that affect core state powers, and the likelihood of internal differentiation increases with the supranational centralization of these policies. External differentiation in the area of core state powers does not exist because states opposed to supranational centralization in policy areas relating to noncore state powers refuse the supranational integration of core state powers $a$ fortiori. They do, however, seek access to the internal market if demand based on externalities and economies of scale is high. This demand produces the external differentiation of non-core state powers. 
Starting from these theoretical considerations and their broad empirical fit with patterns of differentiated integration across core and non-core state powers, we now turn to case studies of specific policy areas that represent different configurations of state powers and differentiation. Market integration is the most important policy area of European integration involving non-core state powers. It is characterized by a combination of significant external differentiation while lacking internal differentiation. It is also an important contrast case for the three case studies of integration regarding core state powers that follow since it allows us to capture the full range or variation of horizontal differentiation (see Gerring 2007: 97-8). Monetary policy is the policy showing the largest extent of internal differentiation but no external differentiation in the EU. The Area of Freedom, Security, and Justice (AFSJ) pertains to policies of border control and cross-border police and judicial cooperation. (p.198) It is also an interesting case because it combines internal and external differentiation. Finally, we examine security and defence policy, which is an area involving core state powers with 'almost uniform' integration. It is characterized by only very weak internal differentiation.

10.5 Case Studies of Differentiated Integration: The Market, EMU, AFSJ, and Security and Defence Policy

10.5.1 Market Integration: The Bedrock of Non-core State Powers

The EU's internal market shapes the patterns of state-market relations in Europe. Internal market policies affect citizens as consumers, producers, traders, or employees. Even though market integration has been at the heart of the European integration project since the 1950s, we will concentrate our discussion on the SEA, which can be considered a major milestone of the socalled Relance Européenne of the 1980s. By examining the enactment of the internal market programme in the 1980s we argue that market integration in Europe can be explained without necessarily referring to the post-Second World War context. 
Starting from the demand side, how can we account for the move towards the adoption of the internal market programme? The key explanatory factor is economic interdependence, which can be viewed as a necessary condition for market integration to ensue. Increasing levels of economic interdependence generate policy externalities, which in turn create a demand for integration by regulation and supranational policy coordination (see Moravcsik 1991; Mattli 1999; Mattli and Stone Sweet 2012). Policy coordination can be either geared towards eliminating barriers to trade (negative integration) or correcting for market failures (positive integration), e.g. via means of economic or social regulation (see Scharpf 1999). Interest groups and transnational market actors were among the main demandeurs of supranational rules. The purpose of these rules was to destabilize and replace domestic rules and regulations, which hindered the free exchange of goods and services. Moreover, supranational actors-the Commission and the Court-readily provided supranational rules and played a crucial role in advancing both market-making as well market-correcting measures (Stone Sweet and Sandholtz 1997; Stone Sweet and Brunell 1998; Fligstein and Stone Sweet 2002; Mattli and Stone Sweet 2012). This view is partially challenged by research, which claims that the demand for integration is not funneled through transnational and supranational channels, but is provided by governments, which respond to demands by dominant domestic interest groups (most notably producer groups). According to this perspective, economic interdependence is still a (p.199) necessary condition for market integration, but successful market integration could only ensue once the economic policy preferences of the governments in France, Germany and the UK converged in the mid-1980s. Governments in these three member states turned to 'neoliberal' economic policies, following the perceived failure of Keynesian economic policies (see Moravcsik 1991, 1998). ${ }^{2}$ In sum, the lack of internal differentiation in market-making policies rests on the following dynamics. First, economic interdependence was the critical driving force for market integration since policy externalities and economies of scale exercised a strong effect on all EU member states. Second, since the benefits of market integration were not evenly distributed among all EU member states, the economically weaker 'southern' states demanded compensatory measures from the economically stronger 'northern' states, most notably Germany, France and the UK. By expanding the structural funds, market-integration was made sufficiently attractive for the economically weaker and less competitive member states (Moravcsik 1998: 367). 
Yet, interdependence did not only generate a demand for market integration inside the community. Market integration is not a case of uniform integration, as we have shown previously. It is characterized by external differentiation since non-EU member participate in the EU's internal market. Not only do transnational economic exchanges tend to be more intense and dense than transnational exchanges in non-economic policy fields, they also tend to cover a wider geographical space: globalization is most pronounced in international trade. Market integration thus generates negative externalities for EU outsiders and produces 'geographical spill-over'. The desire to obtain full access to the internal market in order to avoid trade diversion and discrimination has been one of the most important reasons for non-member countries to seek accession to the EU and for the EU to move from six to twenty-seven members (see Mattli 1999). But short of enlargement, market integration has led to external differentiation, of which the establishment of the EEA is an important example. The EEA incorporates the European Free Trade Area (EFTA) countries of Iceland, Liechtenstein, and Norway into the internal market. Moreover, Switzerland is closely associated to the internal market through bilateral treaties. Akin to EU candidate countries, EFTA states faced negative externalities from the single market project, fearing discrimination through diversions in trade and investments (see Mattli 1999). As a result, they took up the Commission's idea of negotiating a global agreement that would ensure access to the single market resulting in the EEA agreement, (p.200) which coincides-with a small time lag-with the deepening of the European integration project through the single market programme.

Turning to the supply side, we need to explore the plausibility of the neofunctionalist and postfunctionalist hypotheses. To inform the neofunctionalist hypothesis, we ask how capable supranational actors are in driving the integration process. Addressing the postfunctionalist hypothesis, we need to know how politicized and contested market integration policies are in the case at hand. We argue that the lack of internal differentiation can be attributed to the low level of political contestation of issues pertaining to market integration. As the autonomy and identity costs of market integration are relatively low, there is no reason for governments to forego the benefits of market integration and seek opt-outs. Moreover, supranational actors-most notably the Commission and the Court-have been the main drivers of market integration, laying the foundation upon which the SEA was constructed (see, for example, Alter and Meunier-Aitshalia 1994; Stone Sweet and Brunell 1998). Yet, the high level of capacities and activism of supranational actors in this policy area has not created identity-driven popular backlashes: the permissive consensus reigned in the early EC member states and the unity of market integration could be preserved. 
Turning to external differentiation, the case of the EEA illustrates that high interdependence with the EU leads to demand for 'outsiders' to participate in the EU's internal market. Yet, two situations of external differentiation need to be distinguished where high levels of demand meet different supply conditions: in the first case, high interdependence coincides with Eurosceptic majorities in non-EU member states, such as in Norway or Switzerland. In these countries, the accession of their country to the EU has been repeatedly rejected by popular referendums. At the same time, these countries have adopted the large majority of internal market rules in order to gain unrestricted access to the vast market in their neighborhood on which they depend for most of their exports and imports. In the second case, countries such as Turkey or Serbia have not been admitted by the EU member states because their governments have long been, and still are to some extent, unwilling to meet the EU's identity-based political conditions for membership, which has stirred domestic opposition in EU member states. They have been associated with the internal market nevertheless because of their strong economic interdependence with the EU and because the EU regards association as a way to tie these countries to its practices and values. In sum, whereas the absence of internal differentiation in the internal market is an effect of high interdependence, supranational activism and low levels of political contestation, external differentiation is a way to deal with high interdependence in spite of high levels of political contestation over a membership perspective.

\section{(p.201) 10.5.2 Core State Powers I: Monetary Policy}

'The monetary system of a people reflects everything that the nation wants, does, suffers, is. ${ }^{3}$ This quote of the Austrian economist Joseph Schumpeter emphasizes that monetary policy is not only a core state power but also a symbol of national identity and community. Monetary policy has traditionally been a monopoly of the state, and transferring this core state power to the EU deprives the state of an important instrument in its macroeconomic toolkit. 
Economic and Monetary Union (EMU) was formally established by the Treaty of Maastricht signed in 1991. It marks a significant leap forward in the integration of monetary policy-and European integration in general. Whereas monetary policy had been a predominantly national competence before, it now became exclusively European. The issue and supply of money as well as the control of money in circulation ceased to be a sovereign right and policy. Interest and exchange rates could not be set by national central banks (or governments) any more. Before EMU, monetary policy integration had remained a matter of intergovernmental coordination in the European Monetary System established in 1979. With EMU, it became supranationally centralized. Monetary policy was fully and permanently transferred to the European System of Central Banks with the European Central Bank (ECB) at its head. Thanks to the independence of the ECB, governments do not have any formal influence on the operation of monetary policy. However, monetary policy is not only one of the most centralized but also the most internally differentiated policy of the EU. Only 18 out of 28 member states are part of the Eurozone.

Monetary policy is thus a suitable case to look into the correlation between the supranational integration of core state powers and internal differentiation. Following the demand-and-supply framework for analysing integration, internal differentiation could either result from heterogeneous demand or heterogeneous supply (willingness and ability). The analysis also needs to take into account that internal differentiation comes in two forms. First, there are those EU member states, which have deliberately opted out from the currency union: Denmark, Sweden, and the UK. By contrast, the new member states joining after the introduction of the Euro were not immediately admitted to the Eurozone but first had to meet the convergence criteria. Six out of the 13 new member states have adopted the Euro in the meantime. As differentiation appears to be a transitional phenomenon in (p.202) the case of most new member states, we focus on the deliberate opt-outs of the old member states.

The opting out of Denmark, Sweden, and the UK are difficult to account for by demand and require a supply-side explanation. The supply-side explanation, in turn, cannot be based on capability. Rather, the rejection of monetary union by these old member states is fundamentally driven by identity concerns and the domestic politicization of integration. As for demand, the opt-out countries are open and trade-dependent economies. Denmark and Sweden in particular conduct roughly $70-75 \%$ of their foreign trade with the rest of the EU. As for capability, neither Denmark nor Sweden would have had any problems in meeting the convergence criteria for EMU, and the UK was also closer to fulfilling them than most of the southern member states that eventually adopted the Euro. As for willingness, the macroeconomic preferences of these three countries for fiscal discipline and inflation targeting were very much in line with the principles of EMU-and again closer to them than the preferences of the southern member states. 
The most plausible explanation for differentiation is therefore the postfunctional one. According to a poll in 1992 (Eurobarometer 38), the UK and Denmark were two of three countries (the third one being Ireland) whose citizens feared most strongly the loss of national identity in European integration. Denmark and the UK were the only two countries in which both the Treaty of Maastricht and the single currency were opposed by majorities. Sweden joined the EU in 1995 as a result of a close accession referendum. From day one, the Euroscepticism of the Swedes has been similar to that of the British and the Danes. In 1995 (Eurobarometer 43), support for European unification was lowest in the UK, Sweden, and Denmark; and the share of respondents with exclusive national identities was even higher in Sweden than in the UK. Weak support for further European integration, a comparatively negative image of the EU, and extremely low support for the Euro have remained consistent features of the public opinion in these three countries. The data support the claim that 'the Euro is about identity politics and political visions of European order' (Risse et al. 1999: 175).

The postfunctional explanation is further strengthened by the observation of an elite-mass divide in these countries. In Denmark and Sweden, it took popular referendums for the mass-level identity-based opposition to the Euro to assert itself against Euro-friendly elites. Even though the British government has rejected supranational monetary integration from the very start, it also constrained its room for manoeuvre by the promise to hold a referendum should it want to introduce the Euro. By contrast, the German constitution does not provide for treaty ratification by popular referendum. As a result, popular majorities against the Euro have not been able to assert themselves against the pro-Euro mainstream parties. Comparatively Eurosceptic (p.203) identities together with domestic institutions, which made it possible for them to constrain government policies, have forced governments to abandon integration policies they considered to be in their economic interest. To this day, the Danish Krone is pegged to the Euro. 
Like all core state powers, the Area of Freedom, Security, and Justice (AFSJ) formerly called Justice and Home Affairs (JHA) -is a latecomer on the scene of European integration. Prior to the nineties, this policy area was hardly a topic on the political agenda. Since then, it has displayed an impressive dynamic. The AFSJ encompasses a broad array of internal security policies, ranging from border checks, asylum and immigration policies, judicial cooperation in civil matters, judicial cooperation in criminal matters, to police cooperation. These policies constitute core state powers par excellence, since they all crucially relate to the capacity of states to provide internal security. With the adoption of the Schengen Agreement in 1985 and its implementation in 1990, border controls between the member countries of the Schengen group have been abolished. The so-called Schengen Area not only abolished border controls, through the Dublin conventions, it also established common rules on visas and police cooperation and set up the Schengen Information System. Closer cooperation in matters of domestic (security) policies can be regarded as a means to fend off some of the negative policy externalities of the free movement of persons (see Kaunert 2005: 464). For instance, Gehring (1998) sees Schengen as an example of 'negative' integration that engenders 'positive' integration in functionally related areas such as asylum policy.

Over time, Schengen became attractive for an increasing number of states. The founding five signatory states (the Benelux countries, France, and Germany) were joined by Austria, Italy, Portugal, and Spain in 1997, to be followed by Greece in 2000 and the members of the Nordic Passport Union (Denmark, Finland, Sweden, Iceland, and Norway) in 2001. In 2007 all accession states from the first round of Eastern enlargement (with the exception of Cyprus) joined the Schengen area. Switzerland became a member in 2008, Liechtenstein in 2011. Since the Schengen regime only united a subset of EC member states at the outset, it can be considered a prominent laboratory of internal differentiation (see Monar 2001). A cooperative arrangement of five EC member states outside the EC framework eventually led to the formal integration of a new policy. The Schengen acquis was finally incorporated into the framework of the EU through a protocol annexed to the Amsterdam Treaty.

Schengen is thus a case of external and internal differentiation. Non-EU member states are members of the Schengen area (Iceland, Norway, (p.204) Switzerland, and Liechtenstein) while some EU member states have decided to remain outside (the UK and Ireland have opted out of Schengen, Cyprus has not yet implemented it, Bulgaria and Romania still have to fulfill the necessary criteria for joining the Schengen group). As to the demand side of integration, there is a clear linkage between the abolition of border controls and the promotion of the 'four freedoms' in the 1980s, which were underpinning the common market project, in particular, the free movement of persons. 
Demand for integration was voiced by governments as well as by nongovernmental actors. Transnationally operating businesses criticized the tedious and time-consuming border controls that were considered to obstruct the smooth movement of goods and persons (Lavenex and Wallace 2005). Schengen explicitly expresses the goal to facilitate the transport and movement of goods at the borders of the contracting parties. This goal is intimately linked to the completion of the internal market and the logic of policy externalities: the gains from market integration can only be fully captured when border controls between the trading states are abolished. This logic found support in the five signatory states of the Schengen agreement. In fact, border controls between the Benelux countries had already been scrapped in 1960.

At the same time, the Schengen rules encountered reluctance in more Eurosceptic states. While its geographic location sets the UK slightly apart from other member states, there seems more to British reluctance than its isolated geographic location, which limits interdependence. The scrapping of border controls was considered an assault on state sovereignty and the UK's identity as 'island nation'. Euroscepticism thus seems to have acted as a constraining force for the question of joining Schengen (see Wiener 1999). As for Ireland, nonparticipation in Schengen is primarily driven by functional concerns, as Schengen membership would have entailed substantive costs by endangering the existence of the Common Travel Area with the UK, Ireland's closest economic partner. In the Irish debate on Schengen, the issue is less politicized and identity concerns are less prominent. Identity concerns play a more prominent role in accounting for the in-between position of Denmark. Denmark's geographic location as a continental country provides good functional reasons for participating in Schengen. At the same time, the common border regime is often perceived as a threat to national identity (Hansen 2002). Immigration is a highly politicized issue in the domestic debate. In the context of the Arab spring in 2011, Denmark returned to temporarily setting up border controls to meet domestic concerns from sections of the public fearing uncontrolled migration from Arab states.

The case of Schengen shows that supply for integration is heterogeneous as it reflects both functional and identity-driven logics. Internal differentiation (p. 205) can be best accounted for by the postfunctionalist hypothesis, which highlights the politicized nature of the Schengen policies and hence the constraining power of Euroscepticism for the course of integration. The limited capacity of non-majoritarian actors, such as the Commission and the Court, to impact the course of integration disconfirms the expectations of the neofunctionalist hypothesis. The governments of the signatory states remain the key actors and hence the main suppliers of integration. Initially, Schengen was not even formally part of the treaties before Amsterdam, and when JHA were introduced as the 'third pillar' of the Maastricht Treaty, decision-making remained intergovernmental. 
As in the case of the internal market, external differentiation is a response to interdependence in the face of identity-driven accession constraints. For example, Norway and Iceland are members of Schengen because of their traditional passport union with Denmark, Sweden, and Finland; and Switzerland and Liechtenstein have joined the Schengen area because they are surrounded by Schengen member countries. For these two countries the interdependencedriven market logic also applies, since Liechtenstein is a member state of the EEA and Switzerland has enacted the free movement of persons with the EU in the bilateral treaties. In the case of Switzerland, membership in the Schengen border control regime (as well as in the Dublin asylum regime) can also be explained by negative externalities due to the closer cooperation of other European states in these policy areas. For example, by limiting the possible locations for applying for asylum, Switzerland increasingly has become a place for so-called asylum shopping.

\subsubsection{Core State Powers III: Security and Defence Policy}

Nation-state control over its armed forces constitutes not only a cornerstone of modern statehood; a state's military is also an expression of its national sovereignty. The areas of security and defence are commonly referred to as an issue of 'high politics' and, as such, they are characteristic of policies that are deemed vital in determining the autonomy, integrity-and hence the survival-of nation-states (Hoffmann 1966). International cooperation, or even integration in matters of security and defence policy should be particularly hard to obtain. As Neo-realists would argue the anarchical and uncertain nature of international politics offers no protection to the security and integrity of states and therefore, governments have to invest in capabilities and forge alliances to defend themselves against potential competitors. National security concerns may not only result from the uneven distribution of military capabilities. States' strategic cultures and identities, which are deeply rooted in foreign and security policy traditions, also play (p.206) an important role in affecting states' security and defence policy interests (see Koenig-Archibugi 2004). Why, then, would states decide to give up sovereignty in an area that lies at the heart of its coercive power and is constitutive of its sovereignty? 
Against the backdrop of the momentous geopolitical shifts brought about by the fall of the iron curtain and German unification, the Treaty of Maastricht introduced the Common Foreign and Security Policy (CFSP), which constituted the 'second pillar' of the new three pillar-structure of the EU and provided the member states of the EU with concrete tools for action by introducing instruments such as 'Joint Action' (Art. J.3). Against the widely perceived failure of the EU to find a joint and adequate response to the wars and atrocities in the Balkans, a revision of CFSP provisions appeared to be overdue only shortly after the Maastricht Treaty entered into force. The Amsterdam Treaty brought about only modest changes, yet it created the post of a High Representative for CFSP. With the Amsterdam Treaty barely ratified, the Kosovo War, which erupted in March 1998, prompted EU governments and the US government to re-define the EU's role in the Balkans. The Franco-British St Malo Declaration of December 1998 called for the EU to develop a 'capacity for autonomous action, backed up by credible military forces, the means to decide to use them and a readiness to do so, in order to respond to international crises'. At the Helsinki European Council meeting of December 1999 the member states pledged to create the appropriate institutional and military infrastructure for the European Security and Defence Policy (EDSP). The ESDP was to be realized and assisted by a range of new institutions and decision-making forums. The Nice Treaty incorporated and formalized the existence of the new institutional structure. Moreover, in 2003, the EU launched its first military operation, a peacekeeping operation in the Former Yugoslav Republic of Macedonia, which it took over from NATO (Operation Concordia).

Compared to the other policies discussed here, integration in the area of security and defence is not only a 'latecomer' but has also strong 'intergovernmental' features, i.e. supranational actors have limited capabilities to affect security and defence policy decisions. Moreover, security and defence is the least territorially differentiated policy area of the policies we compare in this chapter. Only Denmark has opted out of this policy, and non-member states do not formally participate in the EU's defence policy. How can we account for this weak form of internal differentiation? 
Internal differentiation could either result from heterogeneous demand or heterogeneous supply. Demand-side explanations based on differential interdependence do not provide a satisfactory answer since European interdependence in the area of security and defence has remained relatively (p. 207) low. Europeans have depended, and arguably still do, less on each other for achieving security and military effectiveness than on the United States. Transgovernmental exchanges have taken place in the context of NATO rather than in a European context. Even under conditions of high interdependence during the Cold War, the provision of security and defence has always remained an intergovernmental policy. Yet, one could argue that in order to pursue an effective security and defence policy, small member states with limited capabilities should display a higher willingness to cooperate in security and military affairs than member states that have unilateral defence-policy options (Koenig-Archibugi 2004: 194-5). Yet, this explanation does not shed light on the rationale for the Danish opt-out.

As in the case of monetary policy, the most plausible explanation for internal differentiation in security and defence policy is the postfunctional one. On the eve of the ratification of the Maastricht Treaty, Denmark was one of only three countries whose citizens feared most strongly the loss of national identity in European integration. The referendum, which had to be called in Denmark, to enable the passing of the Maastricht Treaty, was held against the backdrop of a strong elite-mass divide on the future course of European integration. The political elites endorsed further integration, while the public was decidedly Eurosceptic. Even though the majority of Danish citizens were in favor of market integration, they were 'opposed to further integration in areas such as foreign policy, defence and a single currency' (Hobolt 2006: 632; Pedersen 2006; Olsen 2007).

Is Denmark simply being the 'odd country out'? Why do we not observe more internal differentiation in the area of security and defence? The lack of supranational actors' capacity to press for further integration as well as the potential of security and defence matters to become subject to politicization actually points towards more rather than less (internal) differentiation. Yet, the low level of supranational centralization in this policy area-which is endogenous to these two factors-has thus far prevented more states from demanding opt-outs. Counterfactually speaking, we would expect to see more internal differentiation if there was, for example, an initiative to form a European army. The inclusion of 'permanent structured cooperation' in the Lisbon Treaty, which allows EU member states to enter into closer cooperation to enhance European defence capabilities, can be interpreted along these lines: Deeper integration is likely to meet a growing resistance of publics that are Eurosceptic and concerned about the implications of further integration on their national identity (as long as these identities are viewed as exclusive). Differentiation can, at least partially, reconcile this tension. 
(p.208) 10.6 Looking Backward to Look Forward: Trajectories of Differentiated Integration

Our analysis has revealed some interesting patterns of differentiated integration in Europe. Most importantly, we find evidence for a link between the 'depth' of integration and increasing differentiation. Our analyses suggest that the higher the level of centralization in a policy area the more likely territorial differentiation in this area becomes. In our selection of policies, defence policy is the least integrated, i.e. centralized policy area and displays only weak internal differentiation with only Denmark having implemented an opt-out. A second example is the EEA-an instance of external differentiation-that ensued as a consequence of the deepening of market integration through the Single Market programme. The deepening of market integration incurred negative externalities for the EFTA states, enticing them to seek closer cooperation with the EU for economic reasons. Note that the high costs imposed by the EEA for the EFTA states-these states have to sacrifice substantive autonomy in market-related policies-have led Austria, Finland, and Sweden to demand EU membership. Deeper integration can thus drive outsiders in and, at the same time, it can drive insiders out. The pulling power is 'functional'-as in the case of the EEA-the pushing power, on the other hand, follows a postfunctionalist logic (see Hooghe and Marks 2009). The postfunctionalist logic tends to characterize integration dynamics in the area of core state powers. Here, identity issues are touched upon, integration is politicized and therefore internal differentiation should increase. At the same time, there is a smaller likelihood of external differentiation in core state powers since outsiders are less willing to accept a supranational integration without a proper representation.

From our perspective, differentiation is likely to increase further. Deeper integration of policy areas is likely to meet a growing resistance of increasingly identity-concerned and Eurosceptic publics. In addition, with an increasing number of member states heterogeneity is likely to grow. From this perspective, differentiation can-at least in parts-reconcile the tension between deepening and widening. The current developments in EMU might lead to a new development in the history of European integration, namely the dropping out of countries from an established policy regime. In the worst of scenarios, the important spill-over dynamics that we identified in this paper, might actually also work as spill-back (see Lindberg and Scheingold 1970: 137).

\section{(p.209) References}

\section{Bibliography references:}

Alter, K., and Meunier-Aitshalia, S. (1994). 'Judicial Politics in the European Community: European Integration and the Pathbreaking Cassis de Dijon Decision', Comparative Political Studies 26 (4): 535-61. 
Fligstein, N., and Stone Sweet, A. (2002). 'Constructing Polities and Markets: An Institutionalist Account of European Integration', American Journal of Sociology 107 (5): 1206-43.

Gehring, T. (1998). 'Die Politik des koordinierten Alleingangs. Schengen und die Abschaffung der Personenkontrollen an den Binnengrenzen der Europäischen Union', Zeitschrift für Internationale Beziehungen 5 (1): 43-78.

Gerring, J. (2007). Case Study Research: Principles and Practices. Cambridge: Cambridge University Press.

Hansen, L. (2002). 'Sustaining Sovereignty: The Danish Approach to the EU'. In Hansen, L., and Wæver, O. (eds.), European Integration and National Identity: The Challenge of the Nordic States. London: Routledge, 50-87.

Hobolt, S.B. (2006). 'How Parties Affect Vote Choice in European Integration Referendums', Party Politics 12 (5): 623-47.

Hoffmann, S. (1966). 'Obstinate or Obsolete? The Fate of the Nation State and the Case of Western Europe', Daedalus 95 (3): 862-915.

Hooghe, L., and Marks, G. (2009). 'A Postfunctionalist Theory of European Integration: From Permissive Consensus to Constraining Dissensus', British Journal of Political Science 39 (1): 1-23.

Kaunert, C. (2005). 'The Area of Freedom, Security and Justice: The Construction of a European Public Order', European Security 14 (4): 459-83.

Koenig-Archibugi, M. (2004). 'Explaining Government Preferences for Institutional Change in EU Foreign and Security Policy', International Organization 58 (1): 137-74.

Lavenex, S., and Wallace, W. (2005). 'Justice and Home Affairs: Towards a “European Public Order"?' In Wallace, H., Wallace, W., and Pollack, M.A. (eds.), Policy-Making in the European Union, 5th edn. Oxford: Oxford University Press, 457-80.

Leuffen, D., Rittberger, B., and Schimmelfennig, F. (2013). Differentiated Integration: Explaining Variation in the European Union. Basingstoke: Palgrave.

Lindberg, L.N., and Scheingold, S.A. (1970). Europe's Would-Be Polity: Patterns of Change in the European Community. Englewood-Cliffs: Prentice-Hall.

Mattli, W. (1999). The Logic of Regional Integration: Europe and Beyond. Cambridge: Cambridge University Press. 
Mattli, W., and Stone Sweet, A. (2012). 'Regional Integration and the Evolution of the European Polity: On the Fiftieth Anniversary of the Journal of Common Market Studies', Journal of Common Market Studies 50 (S1): 1-17.

Monar, J. (2001). 'The Dynamics of Justice and Home Affairs: Laboratories, Driving Factors and Costs', Journal of Common Market Studies 39 (4): 747-64.

\section{(p.210)}

Moravcsik, A. (1991). 'Negotiating the Single European Act: National Interests and Conventional Statecraft in the European Community', International Organization 45 (1): 19-56.

Moravcsik, A. (1998). The Choice for Europe: Social Purpose and State Power from Messina to Maastricht. Ithaca: Cornell University Press.

Olsen, G.R. (2007). 'Denmark and the ESDP'. In Brummer, K. (ed.), The North and the ESDP: The Baltic States, Denmark, Finland and Sweden. Gütersloh: Verlag Bertelsmann Stiftung, 22-33.

Pedersen, K.C. (2006). 'Denmark and the European Security and Defence Policy'. In Bailes, A.J.K., Herolf, G., and Sundelius, B. (eds.), The Nordic Countries and the European Security and Defence Policy. Oxford: Oxford University Press, 3749.

Risse, T., Engelmann-Martin, D., Knopf, H.J., and Roscher, K. (1999). 'To Euro or not to Euro: The EMU and Identity Politics in the European Union', European Journal of International Relations 5 (2): 147-87.

Scharpf, Fritz W. (1999). Governing in Europe: Effective and Democratic? Oxford: Oxford University Press.

Stone Sweet, A., and Brunell, T. (1998). 'Constructing a Supranational Constitution: Dispute Resolution and Governance in the European Community', American Political Science Review 92 (1): 63-81.

Stone Sweet, A., and Sandholtz, W. (1997). 'European Integration and Supranational Governance', Journal of European Public Policy 4 (3): 297-317.

Wiener, A. (1999). 'Forging Flexibility-The British "No" to Schengen', European Journal of Migration and Law 1 (4): 441-63.

Notes:

$\left({ }^{1}\right)$ See Leuffen et al. (2013) for a more detailed exposition. 
$\left({ }^{2}\right)$ These positions obviously refer to the debate among Moravcsik's liberal intergovernmentalism and supranationalism. For an application of these

European integration theories to differentiated integration, see Leuffen et al. (2013).

( $\left.{ }^{3}\right)$ 'Staring into the abyss', The Economist, 12 November 2011, available at <http://www.economist.com/node/21536872>. 